\section{Production and Postproduction Studies with Potted Sunflowers}

\author{
Laurence C. Pallez, ${ }^{1}$ \\ John M. Dole, ${ }^{2}$ and \\ Brian E. Whipker ${ }^{3}$
}

Additional IndeX words. daminozide, paclobutrazol, Promalin, photoperiod, Helianthus annuus

Summary. Sunflower (Helianthus annuus) has potential as a potted flowering plant due to short crop time, ease of propagation, and attractive flowers but postharvest life is short and plants can grow too tall. Days from sowing to anthesis differed significantly among six sunflower cultivars and ranged from 52 days for 'Big Smile' to 86 days for 'Elf' and 'Pacino.' Height ranged from 6.0 inches $(15.2 \mathrm{~cm})$ for 'Big Smile' to 14.9 inches $(37.8 \mathrm{~cm})$ for 'Pacino', postproduction life ranged from 10 days for 'Elf' and 'Pacino' to 15 days for 'Big Smile', and postproduction chlorosis ratings ( 1 to 5 , with 5 the least) ranged from 5.0 for 'Teddy Bear' to 4.4 for 'Big Smile' after 5 days and 4.2 for 'Teddy Bear' to 3.1 for 'Sunspot' after 10 days. Promalin (a gibberellin and benzyladenine mixture) applied at 62.5 to $500 \mathrm{ppm}$ $\left(\mathrm{mg} \cdot \mathrm{L}^{-1}\right)$ was not commercially useful in extending postproduction life. Increasing pot size from 4 to 6 inches $(10$ to $15 \mathrm{~cm})$ in diameter decreased postproduction life and plants in 5inch-diameter $(13 \mathrm{~cm})$ pots were

Department of Horticulture and Landscape Architec ture, Oklahoma State University, Stillwater, OK 74078 6027.

Approved for publication by the director of the Okla homa Agricultural Experiment Station (OAES). Our research was supported in part by Alex R. Masson, Inc., Linwood, Kan., and OAES under project H-2119. Appreciation is expressed to Modena Seed, Benary Seed, and Sakata Seed for seed.

${ }^{1}$ Graduate research assistant, currently at Color Spot Nurseries, Inc., 7960 Cagnon Rd., San Antonio, TX 78252

${ }^{2}$ Professor, currently at Dept. of Horticultural Science, North Carolina State Univ., Box 7609, Raleigh, NC 27695-7609

${ }^{3}$ Floriculture extension specialist, Dept. of Horticultural Science, North Carolina State University, Raleigh, NC 27695 tallest. Pots with three plants flowered more quickly than those with one or five plants and pots with five plants had 1 day shorter postharvest life than those with one or three pots. All cultivars were facultative short-day plants, except for 'Sundance Kid', which was day neutral. Storing potted sunflowers at $41^{\circ} \mathrm{F}\left(5^{\circ} \mathrm{C}\right)$ for 1 week did not reduce postproduction life, which was 11 to $12 \mathrm{~d}$; however, 2 weeks of cold storage resulted in foliar damage. Three cultivars were found to be most suitable for pot production, 'Elf', 'Pacino' and 'Teddy Bear', with one or three plants per 6-inch pot and sprayed with daminozide (B-Nine) at $8,000 \mathrm{ppm}$, or drenched with paclobutrazol (Bonzi) at $2 \mathrm{mg} /$ pot (a.i.) $(28,350 \mathrm{mg}=1.0 \mathrm{oz})$.

S unflowers are an important cut flower and garden ornamental, and could make a profitable potted flowering plant due to short crop time, ease of propagation and attractive flowers. However, sunflowers can become disproportionately large relative to their container size, especially when grown in a greenhouse, and can be difficult to keep adequatelywatered in the postharvest environment (Whipker and Dasoju, 1998).

The most important commercial potted sunflower cultivars are 'Big Smile', 'Elf', 'Pacino', 'Sundance Kid', 'Sunspot', and 'Teddy Bear' (Dasoju et al., 1998). 'Big Smile', 'Pacino', and 'Elf' are dwarf cultivars, but require the application of growth regulators to produce properly proportioned plants. The plant height should be 1.5 to 2.0 times the height of the pot. Whipker et al. (1998) and Whipker and McCall (2000) produced marketable-sized sunflowers in 6-inch diameter $\left[73\right.$ inch $^{3}$ (1.2 L)] pots with paclobutrazol drench concentrations of 2 to $4 \mathrm{mg} /$ pot (a.i.) or with daminozide spray concentrations of 4,000 to 8,000 ppm.

Sunflower postharvest life is relatively short as shown by a preliminary experiment (data not published) in which the flowers remained acceptable for up to 2 weeks, but the lower foliage began to yellow and senesce immediately after anthesis. Whipker and Dasoju (1997) recommended growing sunflowers with 150 ppm nitrogen constant liquid fertilization for maximum shelf life, with fertilization discontinued 7 to $10 \mathrm{~d}$ before anthesis.

Older leaf senescence must be delayed to improve the longevity and quality of the crop. Treatments with Promalin (Abbott Laboratories, North Chicago, Ill.), a gibberellin $\left(\mathrm{GA}_{4+7}\right)$ and benzyladenine (BA) mixture, at $250 \mathrm{ppm}$ reduced leaf senescence of potted lilies (Lilium hybrid) (Funnell and Heins, 1998). Han (1997) showed that Promalin concentrations as low as 25 ppm were effective in reducing leaf yellowing in easter lilies (Lilium longiflorum). Flower longevity increased when 'Stargazer' hybrid lily (Lilium'Stargazer') and easter lily were sprayed with Promalin at $100 \mathrm{ppm}$ (Ranwala and Miller, 1998; Ranwala et al., 2000).

No information is available concerning the influence of pot size or number of plants per pot on production and postproduction life of potted sunflowers. However, sunflowers for cut flower production grown in bedding plant flats with 10 plants per flat [24 inch $^{2}\left(156 \mathrm{~cm}^{2}\right)$ area, 38 inch $^{3}$ $(620 \mathrm{~mL}) \mathrm{medium} / \mathrm{plant}$ ] reached anthesis in fewer days and were taller than plants grown with 72 plants per flat $\left[5\right.$ inch $^{2}\left(32 \mathrm{~cm}^{2}\right)$ area, 5 inch $^{3}(85$ $\mathrm{mL}$ ) medium/plant] (Dole, 1999).

Postproduction longevity of many plants has been extended by holding or shipping at low temperatures (Halevy and Mayak, 1981). Storage of plants at low temperatures of 34 to 41 ${ }^{\circ} \mathrm{F}$ ( 1 to $5{ }^{\circ} \mathrm{C}$ ) decreased respiration and ethylene production, and increased postproduction life of potted flowering plants (Nell and Noordegraaf, 1991). Duration of storage can also affect plant quality (Gibbs et al., 1989). Some plants tolerate low temperatures for a short time, but prolonged exposure to the same temperature can cause chilling injury (Marousky and Harbaugh, 1980).

The objectives of our studies were to determine optimum production techniques and to lengthen the postproduction life of potted sunflower plants by examining cultivar, pot size, plant number per pot, growth regulators, photoperiod, and cold storage.

\section{Materials and methods}

Plant culture. Seeds were sown in 1206-cell packs [3 inch ${ }^{3}\left(50 \mathrm{~cm}^{3} /\right.$ cell) ] filled with a peat-based commercial medium (Redi Earth, Scotts-Sierra Horticultural Products Co., Marysville, Ohio). Plants were transplanted into final containers filled with peat-based commercial media (BMl; Berger 
peatmoss, Saint-Modeste, Que., Canada) and spaced $12 \times 12$ inches $(30 \mathrm{~cm})$ apart. Plants were grown in a corrugated polycarbonate-covered greenhouse set at $72 / 59{ }^{\circ} \mathrm{F}(22 / 15$ $\left.{ }^{\circ} \mathrm{C}\right)$ day/night temperatures. Plants were fertigated at each irrigation with $250 \mathrm{ppm} N$ from a premixed commercial $20 \mathrm{~N}-4.4 \mathrm{P}-16.6 \mathrm{~K}$ fertilizer (Peter's Professional 20-10-20, Scott's Co., Marysville, Ohio). All data were subjected to analysis of variance using the general linear models (GLM) procedure (SAS Inst., Cary, N.C.).

EXPeriments 1 to 4. Four experiments were conducted using six dwarf sunflower cultivars: 'Big Smile', 'Elf' (Expts. 1 and 4 only), 'Pacino', 'Sundance Kid', 'Sunspot' and 'Teddy Bear'. Seeds were sown on 12 Nov.1998 (Expts. 1 to 3) or 6 Dec. 1999 (Expt. 4) and transplanted on 30 Nov. 1999 (Expts. 1 to 3) or 26 Dec. 1999 (Expt. 4) into the final round plastic pot. Plants were grown under natural daylengths (except Expt. 4) which ranged from 9 h 54 min at transplanting to $10 \mathrm{~h} 43 \mathrm{~min}$ at the average date of anthesis.

At flowering, date and plant height from medium to top of plant (tallest plant if more than one plant in pot) were recorded. Plants were moved to the postproduction area $\left[15 \mu \mathrm{mol} \cdot \mathrm{m}^{-}\right.$ $\left.{ }^{2} \cdot \mathrm{s}^{-1}, 68 \pm 4^{\circ} \mathrm{F}\left(20 \pm 2^{\circ} \mathrm{C}\right)\right]$ when they reached marketable stage (flowering, outer petals perpendicular to base) and foliar chlorosis ratings were taken after 5,10 , and $15 \mathrm{~d}$ and termination date (date of unacceptable appearance) was recorded. Foliar chlorosis ratings ranged from 1 to 5 : 1 = plants with $\geq 25 \%$ chlorotic leaves, 2 = plants with $\geq 10 \%$ and $<25 \%$ chlorotic leaves, $3=$ plants with $\geq 5 \%$ and $<10 \%$ chlorotic leaves, $4=$ plants with $<5 \%$ chlorotic leaves, and $5=$ plants without chlorotic leaves. Data collected ceased when $\geq 25 \%$ leaves were chlorotic and $\geq 50 \%$ of the petals on the primary flower had senesced or abscissed. For Expt. 4, the number of nodes was also recorded at flowering, postproduction life was not determined, and foliar chlorosis was not rated.

Ten single-plant replications were used in each experiment. Plants were arranged in a completely randomized design on greenhouse benches and in the postproduction area.

Pot size (EXPT. 1). 'Big Smile', 'Elf', 'Pacino', 'Sundance Kid', 'Sunspot' and 'Teddy Bear' plants were transplanted into 4,5 , or 6 -inch-diameter $\left[24,31\right.$, or 55 inch $^{3}(0.4,0.5$ or $0.9 \mathrm{~L}$ ) volume] pots with 1 plant/pot, resulting in a $6 \times 3$ factorial arrangement of six cultivars and three pot sizes. Pots were spaced at $11 \times 11$ inches $(28 \mathrm{~cm})$.

Promalin rates (expt. 2). 'Big Smile', 'Pacino', 'Sundance Kid', 'Sunspot' and 'Teddy Bear' plants were transplanted into 6-inch-diameter pots with 1 plant/pot and sprayed with 0 , $62.5,125,250$, or 500 ppm Promalin at anthesis, resulting in a $5 \times 5$ factorial arrangement of five cultivars and five Promalin concentrations. Promalin solution was applied at $0.005 \mathrm{gal} / \mathrm{ft}^{2}$ $\left(0.2 \mathrm{~L} \cdot \mathrm{m}^{-2}\right)$.

Plants per pot (expt. 3). 'Big Smile', 'Pacino', 'Sundance Kid', 'Sunspot', and 'Teddy Bear' plants were transplanted into 6-inch-diameter pots with 1,3 , or 5 plants/pot, resulting in a $5 \times 3$ factorial arrangement of five cultivars and three different numbers of plants per pot.

Photoperiod (expt. 4). 'Big Smile', 'Elf', 'Pacino', 'Sundance Kid', 'Sunspot' and 'Teddy Bear' plants were transplanted into 6-inch-diameter pots (1 plant/pot), and placed under 8-, 12-, or 16-h photoperiods, resulting in a $6 \times 3$ factorial arrangement of six cultivars and three photoperiods. The 8 -h photoperiod received $8 \mathrm{~h}$ of natural daylight (0830 to $1630 \mathrm{HR}, 740$ $\mu \mathrm{mol} \cdot \mathrm{m}^{-2} \cdot \mathrm{s}^{-1}$ maximum daily intensity) concurrent with $8 \mathrm{~h}$ of incandescent light $\left(6 \mu \mathrm{mol} \cdot \mathrm{m}^{-2} \cdot \mathrm{s}^{-1}\right)$. The 12 -h photoperiod received $8 \mathrm{~h}$ of natural daylight along with $4 \mathrm{~h}$ of concurrent incandescent light and $4 \mathrm{~h}$ of day extension incandescent light. The 16-h photoperiod received 8 h of natural daylight and an additional $8 \mathrm{~h}$ of day extension provided by incandescent lights. Thus, each treatment had $8 \mathrm{~h}$ of natural daylight and $8 \mathrm{~h}$ of incandescent light. Ten single plant replications were used and cultivars were arranged in a completely randomized design in each photoperiod.

Cold storage (expt. 5). Seeds of 'Pacino' and 'Teddy Bear' were sown on 25 Mar. 1999 and seedlings were transplanted into 6-inch-diameter pots on 15 Apr. 1999. The plants were grown under natural daylengths, which ranged from $13 \mathrm{~h} 6 \mathrm{~min}$ at transplanting to $14 \mathrm{~h} 26 \mathrm{~min}$ at the average date of anthesis. One-half of the plants of each cultivar received a $8,000 \mathrm{ppm}$ daminozide (Uniroyal
Chemical, Middlebury, Conn.) foliar spray applied at $0.005 \mathrm{gal} / \mathrm{ft}^{2} 14 \mathrm{~d}$ after potting. As plants reached anthesis, sets of three plants within each treatment were removed from the greenhouse. One plant was immediately placed in the postproduction area (control); two plants were placed in a cooler at $41{ }^{\circ} \mathrm{F}$. One plant was removed from the cooler after 1 week and the other after 2 weeks. Plants were then transferred to the postproduction area where the termination date was recorded. Five single plant replications were used and plants were arranged in a completely randomized design in the postproduction area.

Cultivar, plant number/pot, AND GROWTH RETARDANT (EXPT. 6). Seeds of 'Pacino' and 'Teddy Bear' were sown on 21 Dec. 1999 and seedlings were transplanted into 6-inchdiameter pots on $20 \mathrm{Jan} .2000$. The plants were grown under natural daylengths, which ranged from $10 \mathrm{~h} 5$ min at transplanting to $12 \mathrm{~h} 35 \mathrm{~min}$ at the average date of flowering. One or three seedlings were planted per pot and sprayed with water, $8,000 \mathrm{ppm}$ daminozide applied at $0.005 \mathrm{gal} / \mathrm{ft}^{2}$, or drenched with $2 \mathrm{mg} /$ pot (a.i.) paclobutrazol (Uniroyal Chemical, Middlebury, Conn.) $14 \mathrm{~d}$ after planting, resulting in a $2 \times 2 \times 3 \times 2$ factorial arrangement of two cultivars, two different plant numbers per pot, three plant growth regulators and two locations. Data collected were anthesis date, plant height from medium to top of tallest plant, and flower diameter ('Pacino' only). Ten single-plant replications were used and arranged in a completely randomized design on the greenhouse benches.

\section{Results and discussion}

Cultivar (eXPt. 1). 'Pacino' and 'Elf' required the greatest number of days to reach anthesis, were the tallest, and had the shortest postharvest life (Table 1). 'Big Smile' required the fewest number of days to reach anthesis, was the shortest, and had the longest postharvest life. 'Teddy Bear' had the least foliar chlorosis with a 5.0 rating (with 5 the least foliar chlorosis) after $5 \mathrm{~d}$ and a 4.2 rating after $10 \mathrm{~d}$ in the postproduction environment (Table 1). 'Sunspot' had the most foliar chlorosis, 3.1 rating, after $10 \mathrm{~d}$. Most plants of all cultivars were not marketable at $15 \mathrm{~d}$ after anthesis. 
Table 1. Effect of cultivar, pot size, Promalin sprays, and number of plants per pot on sunflower production and postproduction life. Data are means of 30 to 50 plants per treatment. No significant interactions between cultivar and plant number per pot, Promalin sprays or pot size occurred; Expts. 1, 2, and 3.

\begin{tabular}{|c|c|c|c|c|c|}
\hline \multirow[b]{2}{*}{ Treatment } & \multirow{2}{*}{$\begin{array}{l}\text { Days to } \\
\text { anthesis }^{\mathrm{z}} \\
\text { (d) }\end{array}$} & \multirow{2}{*}{$\begin{array}{c}\text { Ht } \\
{[\text { inches }(\mathrm{cm})]}\end{array}$} & \multirow{2}{*}{$\begin{array}{c}\begin{array}{c}\text { Post- } \\
\text { production } \\
(d)\end{array} \\
\end{array}$} & \multicolumn{2}{|c|}{$\begin{array}{c}\text { Foliar chlorosis }^{y} \\
\text { Days in postproduction }\end{array}$} \\
\hline & & & & 5 & 10 \\
\hline \multicolumn{6}{|c|}{ Cultivar main effect (Expt. 1) } \\
\hline Big Smile & 52 & $6.0(15.2)$ & 15 & 4.4 & 3.7 \\
\hline Elf & 86 & $14.5(36.8)$ & 10 & 4.7 & 4.0 \\
\hline Pacino & 86 & $14.9(37.8)$ & 10 & 4.6 & 3.7 \\
\hline Sundance Kid & 68 & $14.2(36.1)$ & 14 & 4.8 & 3.6 \\
\hline Sunspot & 66 & $8.5(21.6)$ & 12 & 4.5 & 3.1 \\
\hline Teddy Bear & 68 & $9.0(22.9)$ & 13 & 5.0 & 4.2 \\
\hline Significance & & & & & \\
\hline $\mathrm{LSD}_{0.05}$ & 2 & $0.1(0.2)$ & 1 & 0.2 & 0.3 \\
\hline \multicolumn{6}{|c|}{ Pot size $\{$ diameter $[$ inches $(\mathrm{cm})]\}$ main effect (Expt. 1) } \\
\hline $4(10)$ & 71 & $11.0(27.9)$ & 13 & 4.7 & 3.8 \\
\hline $5(13)$ & 71 & $11.6(29.5)$ & 13 & 4.7 & 3.6 \\
\hline $6(15)$ & 71 & $11.0(27.9)$ & 12 & 4.6 & 3.6 \\
\hline Significance & NS & $\mathrm{Q}^{\star \star}$ & $L^{* *} Q^{\star}$ & NS & NS \\
\hline \multicolumn{6}{|c|}{ Promalin $\left[\mathrm{ppm}\left(\mathrm{mg} \cdot \mathrm{L}^{-1}\right)\right]$ main effect (Expt. 2) } \\
\hline 0 & 70 & $10.0(25.4)$ & 13 & 4.6 & 3.4 \\
\hline 62.5 & 68 & $9.9(25.1)$ & 12 & 4.6 & 3.7 \\
\hline 125.0 & 68 & $10.5(26.7)$ & 12 & 4.6 & 3.6 \\
\hline 250.0 & 68 & $10.7(27.2)$ & 11 & 4.6 & 3.7 \\
\hline 500.0 & 69 & $10.6(26.9)$ & 11 & 1.4 & 2.7 \\
\hline Significance & NS & $\mathrm{L}^{*}$ & $\mathrm{~L}^{\star *}$ & NS & $Q^{\star *}$ \\
\hline \multicolumn{6}{|c|}{ Plants/pot main effect (Expt. 3) } \\
\hline 1 & 70 & $10.0(25.4)$ & 13 & 4.6 & 3.4 \\
\hline 3 & 67 & $10.1(25.7)$ & 13 & 4.6 & 3.5 \\
\hline 5 & 70 & $11.6(29.5)$ & 12 & 4.5 & 3.4 \\
\hline Significance & $Q^{\star \star}$ & NS & $\mathrm{L}^{\star \star}$ & NS & NS \\
\hline
\end{tabular}

${ }^{\mathrm{z} F r o m}$ seed sown on 12 Nov. 1998

${ }^{y}$ Foliar chlorosis rating $1-5$, with 5 having the least chlorosis.

Ns, ${ }^{\star,}{ }^{\star \star}$ Nonsignificant or significant at 0.05 or 0.01 ; linear $=\mathrm{L}$, quadratic $=\mathrm{Q}$.

Only three of the six sunflower cultivars were acceptable as potted plants: 'Elf', 'Pacino' and 'Teddy Bear' had an acceptable plant height of 1.5 to 2 times the pot depth, proper balance between foliage and flower, and a postproduction time of $10 \mathrm{~d}$ or more (Tables 1 and 2). 'Big Smile' plants were too short with very small flowers while 'Sundance Kid' plants were too tall, with long stems and few leaves resulting in unattractive plants. The flowers of 'Sunspot' were often malformed, and petals did not expand. 'Elf' gave similar results to 'Pacino' and the two cultivars could be interchangeable.

Pot size (EXPT. 1). A quadratic relationship existed between pot size and plant height such that plants in the 5 -inch pots were taller than in 4- or 6inch pots (Table 1 ). The 4 -inch pots dried out quickly, which could have reduced plant height and would increase irrigation requirements. On the other hand, plants in the 6-inch pots did not dry out for 1 to 2 weeks after planting which reduced fertilization application and height. Dole (1999) noted that increasing plant number per flat decreased sunflower stem length. While postproduction life of plants in the 6-inch pots was also one day less than that of plants in 4- or 5inch pots, this would not likely be noticeable by sunflower growers and consumers. Pot size had no effect on days to anthesis or foliar chlorosis ratings.

Promalin rates (expt. 2). When applied at flowering, increasing Promalin concentration linearly increased height and decreased postharvest life (Table 1). Promalin did not influence days to anthesis or foliar chlorosis rating at $5 \mathrm{~d}$ after placement in the postproduction environment. However, plants treated with 0 or 500 ppm Promalin had the greatest foliar chlorosis after $10 \mathrm{~d}$. Promalin did not produce sufficient positive results to be commercially useful in extending postproduction life or reducing foliar chlorosis of sunflowers.

Plant number per pot (expt. 3). Three plants per pot reduced days to flowering by $3 \mathrm{~d}$ compared to one or five plants per pot (Table 1). Three plants per pot may have reduced time to anthesis compared with one plant/ pot due to stress caused by competition for nutrients, water and light (Bernier et al., 1981). However, five plants per pot delayed anthesis and linearly shortened postproduction life (Table 1). Pots with five plants wilted readily which significantly reduced postproduction life, but surprisingly had no influence on plant foliar chlorosis. Number of plants per pot did not influence plant height or foliar chlorosis ratings. Three plants per pot gave a fuller look to the pot, which may make it more attractive to consumers.

Photoperiod (expt. 4). All sunflower cultivars grown with the $16-\mathrm{h}$ photoperiod flowered later than with the 8- or 12-h photoperiods, except 
Table 2. Effect of cultivar and 8, 12, or 16-h photoperiods on sunflower growth. Data are means of 10 plants per treatment (Expt. 4).

\begin{tabular}{|c|c|c|c|c|}
\hline Cultivar & $\begin{array}{c}\text { Photoperiod } \\
\text { (h) }\end{array}$ & $\begin{array}{l}\text { Days to } \\
\text { anthesis }^{\mathrm{z}} \\
\text { (d) }\end{array}$ & $\begin{array}{c}\mathbf{H t} \\
{[\text { inches }(\mathrm{cm})]}\end{array}$ & $\begin{array}{c}\text { Nodes } \\
\text { (no.) }\end{array}$ \\
\hline \multirow[t]{3}{*}{ Big Smile } & 8 & 56 & $6.5(16.6)$ & 10 \\
\hline & 12 & 54 & $8.7(22.0)$ & 9 \\
\hline & 16 & 61 & $11.0(27.9)$ & 11 \\
\hline Significance & & $\mathrm{L}^{* * *} \mathrm{Q}^{\star * *}$ & $\mathrm{~L}^{* * *}$ & $\mathrm{~L}^{*}$ \\
\hline \multirow[t]{3}{*}{ Elf $(E)$} & 8 & 77 & $13.7(34.7)$ & 23 \\
\hline & 12 & 82 & $17.5(44.4)$ & 26 \\
\hline & 16 & 83 & $20.9(53.0)$ & 26 \\
\hline Significance & & $\mathrm{L}^{* * *}$ & $\mathrm{~L}^{* * *}$ & $\mathrm{~L}^{* \star}$ \\
\hline \multirow[t]{3}{*}{ Pacino } & 8 & 78 & $14.3(36.3)$ & 23 \\
\hline & 12 & 80 & $16.6(42.2)$ & 24 \\
\hline & 16 & 84 & $22.0(55.9)$ & 26 \\
\hline Significance & & $\mathrm{L}^{* * *}$ & $\mathrm{~L}^{* \star *} \mathrm{Q}^{\star}$ & $\mathrm{L}^{*}$ \\
\hline \multirow[t]{3}{*}{ Sundance Kid } & 8 & 66 & $13.8(35.0)$ & 14 \\
\hline & 12 & 65 & $15.5(39.3)$ & 13 \\
\hline & 16 & 66 & $13.8(35.1)$ & 13 \\
\hline Significance & & NS & NS & NS \\
\hline \multirow[t]{3}{*}{ Sunspot } & 8 & 64 & $9.0(22.8)$ & 13 \\
\hline & 12 & 63 & $10.8(27.4)$ & 12 \\
\hline & 16 & 77 & $20.7(52.5)$ & 22 \\
\hline Significance & & $\mathrm{L}^{* * *} \mathrm{Q}^{\star *}$ & $\mathrm{~L}^{* * *} \mathrm{Q}^{* * *}$ & $\mathrm{~L}^{* * *} \mathrm{Q}^{\star *}$ \\
\hline \multirow[t]{3}{*}{ Teddy Bear } & 8 & 74 & $10.4(26.4)$ & 19 \\
\hline & 12 & 72 & $12.3(31.3)$ & 16 \\
\hline & 16 & 87 & $15.0(38.0)$ & 23 \\
\hline Significance & & $\mathrm{L}^{\star \star *} \mathrm{Q}^{\star \star *}$ & $\mathrm{~L}^{* \star *}$ & $\mathrm{~L}^{* \star *} \mathrm{Q}^{\star \star *}$ \\
\hline
\end{tabular}

${ }^{\mathrm{z} F r o m}$ seed sown on 6 Dec. 1999

$\mathrm{Ns},{ }^{\star \star * *},{ }^{\star \star *}$ Nonsignificant or significant at $0.05,0.01$, or 0.001 ; linear $=\mathrm{L}$, quadratic $=\mathrm{Q}$. for 'Sundance Kid' for which photoperiod had no effect (Table 2). All cultivars were facultative short day plants except for 'Sundance Kid' which was day neutral (Table 2). Robinson et al. (1967) and Schuster (1985) also noted that some sunflower cultivars were short day plants and others were day neutral.

Long photoperiods increased plant height for all cultivars except 'Sundance Kid' (Table 2). While all treatments received 8 -h of incandescent light, the 8-h photoperiod received $8 \mathrm{~h}$ of incandescent light concurrent with $8 \mathrm{~h}$ of natural sunlight and the $16-\mathrm{h}$ photoperiod received $8 \mathrm{~h}$ of incandescent light after $8 \mathrm{~h}$ of natural sunlight. The $8 \mathrm{~h}$ of incandescent light after natural sunlight in the 16-h photoperiod may have induced stem elongation due to the high amount of far-red light from incandescent lamps. Light quality is only partially the reason for increasing height with longer daylengths as node numbers for the 16-h photoperiod were also greater than the 8- or 12-h photoperiods for all cultivars except 'Elf' and 'Sundance Kid'; increasing number of nodes would have also increased height.

Cold storage (eXPT. 5). One to two weeks of cold storage at $4 \mathrm{l}^{\circ} \mathrm{F}$ had

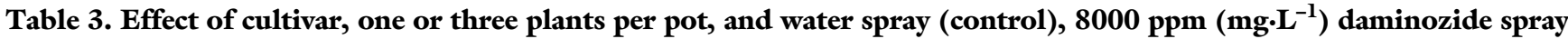
or $2 \mathrm{mg} /$ pot $^{\mathrm{z}}$ (a.i.) paclobutrazol drench on sunflower days to flowering, height, and flower diameter. Data are means of 10 plants per treatment (Expt. 6).

\begin{tabular}{|c|c|c|c|c|c|}
\hline Cultivar & $\begin{array}{l}\text { Plants } \\
\text { per pot }\end{array}$ & $\begin{array}{c}\text { Growth } \\
\text { retardant }\end{array}$ & $\begin{array}{c}\text { Days to } \\
\text { flowering }\end{array}$ & $\begin{array}{c}\text { Ht } \\
{[\text { inches }(\mathbf{c m})]}\end{array}$ & $\begin{array}{l}\text { Flower diam } \\
\text { [inches }(\mathrm{cm})]\end{array}$ \\
\hline \multirow[t]{4}{*}{ Pacino } & 1 & Control & 75 & $14.4(36.6)$ & $4.8(12.3)$ \\
\hline & & Paclobutrazol & 82 & $8.0(20.4)$ & $4.0(10.2)$ \\
\hline & 3 & Control & 74 & $13.6(34.6)$ & $4.8(12.2)$ \\
\hline & & Daminozide & 77 & $10.0(25.4)$ & $4.6(11.6)$ \\
\hline & & Daminozide & 69 & $5.7(14.6)$ & --- \\
\hline & & Paclobutrazol & 68 & $5.6(14.3)$ & --- \\
\hline & 3 & Control & 64 & $9.2(23.3)$ & --- \\
\hline & & Daminozide & 64 & $6.0(15.2)$ & --- \\
\hline & & Paclobutrazol & 65 & $6.1(15.4)$ & --- \\
\hline Growth retardant $(\mathrm{G})$ & & & $* * *$ & $* * *$ & ** \\
\hline \multirow{2}{*}{\multicolumn{2}{|c|}{ Significant interactions $(P \leq 0.05)$}} & & None & $\mathrm{C} \times \mathrm{P}$ & None \\
\hline & & & & $\mathrm{C} \times \mathrm{G}$ & \\
\hline
\end{tabular}

$\mathrm{z}_{2} 8,350 \mathrm{mg}=1.0 \mathrm{oz}$

yAverage of two measurements, one perpendicular to the other, of open flowers with fully expanded petals. Flower diameter was not collected on 'Teddy Bear'. ${ }^{*, * *, * \star *}$ Significant at $0.05,0.01$, or 0.001 . 
no influence on the postcooler life for 'Pacino' and 'Teddy Bear', which was 11 to $12 \mathrm{~d}$. While cold storage for 2 weeks also did not decrease postcooler life, foliage was cold damaged. Thus, 2 weeks of cold storage would not be commercially useful. The ability to be cold-stored for 1 week allows excess production to be stored for a week and allows plants to be shipped in refrigerated trucks. Consequently, increasing duration of cold storage increased total postproduction life from $12 \mathrm{~d}$ when not stored to $19 \mathrm{~d}$ with 1 week storage. Cultivar and daminozide application had no effect on postcooler and postproduction life (data not presented).

Cultivar, plant number/Pot, AND GROWTH RETARDANT (EXPT. 6). 'Teddy Bear' plants flowered 9 to $14 \mathrm{~d}$ more quickly than 'Pacino' plants and 'Teddy Bear' plants were shorter than 'Pacino' plants (Table 3). Whipker and McCall (1998) also noted that 'Teddy Bear' plants were shorter than 'Pacino.' As in Expt. 3, three plants per pot reduced days to flowering but number of plants per pot did not effect plant height or flower diameter (Table $3)$.

Daminozide and paclobutrazol treatments, following the rates recommended by Whipker and Dasoju (1998), were both effective in reducing plant height, regardless of cultivar (Table 3). However, plants treated with daminozide or paclobutrazol had similar or greater number of days to anthesis compared to the control. Whipker and McCall (2000) also noted that daminozide and paclobutrazol delayed flowering of 'Pacino' and 'Teddy Bear' by 1 to $4 \mathrm{~d}$. While the delay in flowering from the growth regulators was statistically significant, it would not limit commercial production. Daminozide and paclobutrazol decreased flower diameter of 'Pacino' pots with one plant per pot by 0.2 to 0.8 inch ( 1.9 to $2.1 \mathrm{~cm}$ ) compared to the untreated controls; however, the decrease in flower diameter would not be commercially important.

\section{Conclusion}

'Elf', 'Pacino', and 'Teddy Bear' were determined to be the best cultivars for production of potted sunflowers because they had an acceptable height of 1.5 to 2 times the pot depth, proper balance between foliage and flower, and a postproduction time of $10 \mathrm{~d}$ or more. One plant per 6 -inch pot gave excellent results, but three plants per pot might be more appealing to consumers (J. Young, personal communication). A spray of daminozide at $8,000 \mathrm{ppm}$ or a paclobutrazol drench of $2 \mathrm{mg} /$ pot (a.i.) were effective in controlling plant height and making plants more suitable for pot production. A photoperiod of $12 \mathrm{~h}$ is suggested to obtain a profitable high quality crop. Since plants required frequent irrigation, automated irrigation would be best. Promalin is not commercially useful in preventing lower leaf chlorosis. Once sunflowers have reached anthesis, cold storage for one week could extend postproduction life of the potted sunflowers.

\section{Literature cited}

Bernier, G., J.M. Kinet, and R.M. Sachs. 1981. The physiology of flowering. vol. 1. CRC Press, Boca Raton, Fla.

Dasoju, S., M.R. Evans, and B.E. Whipker. 1998. Paclobutrazol drenches control growth of potted sunflowers. HortTechnology 8:235-237.

Dole, J. 1999. Greenhouse specialty cut flower production using bedding plant flats. HortScience 34:545-546 (abstr.).

Funnell, K.A. and R. Heins. 1998. Plant growth regulators reduce postproduction leaf yellowing of potted asiflorum lilies. HortScience 33:1036-1037.

Gibbs, M.M., T.M. Blessington, and J.A. Price. 1989. Dark-storage temperature and duration influences flowering and quality retention of Hibiscus. HortScience 24:646647.

Halevy, A.H. and S. Mayak. 1981. Senescence and postharvest physiology of cut flowers. part 2. Hort. Rev. 3:59-143.
Han, S.S. 1997. Preventing postproduction leaf yellowing in easter lily. J. Amer. Soc. Hort. Sci. 122:869-872.

Marousky, F.J. and B.K. Harbaugh. 1980. Deterioration of foliage plants during transit. Foliage Dig. 3:9-14.

Nell, T.A. and C.V. Noordegraaf. 1991. Simulated transport, postproduction irradiance influence postproduction performance of potted roses. HortScience 26:1401-1404.

Ranwala, A.P. and W.B. Miller. 1998. Gibberellin $_{4+7}$, benzyladenine, and supplemental light improve postharvest leaf and flower quality of cold-stored 'Stargazer' hybrid lilies. J. Amer. Soc. Hort. Sci. 123:563-568.

Ranwala, A.P., W.B. Miller, T.I. Kirk, and P.A. Hammer. 2000. Ancymidol drenches, reversed greenhouse temperatures, post greenhouse cold storage, and hormone sprays affect postharvest leaf chlorosis in easter lily. J. Amer. Soc. Hort. Sci. 125:248253.

Robinson, R.A., L.A. Bernat, H.A. Geise, F.K. Johnson, M.L. Kinman, E.L. Mader, P.M. Oswald, E.D. Putt, C.M. Swallers, and J.H. Williams. 1967. Sunflower development at latitudes ranging from 31 to 49 degrees. Crop Sci. 7:134-136.

Schuster, W.H. 1985. Helianthus annuus, p. 98-121. In: A.H. Halevy (ed.). The handbook of flowering. vol. 5. CRC Press, Boca Raton, Fla.

Whipker, B. and S. Dasoju. 1997. Pot sunflower culture tips. GrowerTalks 61:7071 .

Whipker, B. and S. Dasoju. 1998. Potted sunflower growth and flowering responses to foliar applications of daminozide, paclobutrazol, and uniconazole. HortTechnology 8:86-88.

Whipker, B. and I. McCall. 2000. Responses of potted sunflower cultivars to daminozide foliar sprays and paclobutrazol drenches. HortTechnology 10:209-211.

Whipker, B., S. Dasoju, and I. McCall. 1998. Guide to successful pot sunflower production. Horticulture information leaflet 562. N.C. State Univ. Coop. Ext. Serv., Raleigh. 